\title{
Be Green to Be Innovative: The Role of Government Subsidies
}

\author{
Yingbo $X u^{1}$, Wei Liu ${ }^{1 *}$, Ruihui $P u^{2}$ and Yonghui $X u^{1}$ \\ ${ }^{1}$ Business School, Qingdao University, Qingdao, China, ${ }^{2}$ Faculty of Economics, Srinakharinwirot University, Bangkok, Thailand
}

Corporate environmental investment has long been recognized as a non-market strategy that helps secure both economic and social benefits. However, we know much less about how environmental investment affects corporate innovation. We argue that investment in environmental protection is an important source of institutional legitimacy for firms to secure government resources, thus providing financial support for corporate innovation activities. Using a sample of Chinese industrial firms, we find that firms investing more in environmental protection can receive more government subsidies and then have better innovation performance. This study emphasizes the mechanism of government resources, which enriches our understanding of the effect of environmental investment on corporate innovation.

OPEN ACCESS

Edited by:

Xiao-Guang Yue,

European University Cyprus, Cyprus

Reviewed by:

Songqin Huang, Anhui University, China

Lili Mi,

Griffith University, Australia

Otilia Manta,

Romanian Academy, Romania

*Correspondence:

Wei Liu

wei.liu@qdu.edu.cn

Specialty section:

This article was submitted to

Environmental Economics and

Management,

a section of the journal

Frontiers in Environmental Science

Received: 26 August 2021

Accepted: 17 September 2021

Published: 01 October 2021

Citation:

Xu Y, Liu W, Pu R and Xu Y (2021) Be Green to Be Innovative: The Role of

Government Subsidies.

Front. Environ. Sci. 9:765100.

doi: 10.3389/fenvs.2021.765100
Keywords: environmental investment, corporate innovation, government subsidies, resource allocation, institutional legitimacy, China

\section{INTRODUCTION}

The rapid development of Chinese industrial economy has brought new challenges to the environmental governance (Wang et al., 2018). Increasing environmental pollution not only destroys the ecological environment and threatens the health of the population (Liu et al., 2021), but also hinders economic development (Hao et al., 2018). In the face of severe environmental challenges, the Chinese government had gradually increased its attention to environmental protection and begun to guide firms to increase their investment in environmental protection. Firms are not only the cause of environmental pollution, but also should be responsible for eliminating the negative effects of pollution (Klettner et al., 2014). For firms, pollution emissions are the result of inefficient resource allocation (Porter and Van der Linde, 1995). Therefore, all investments to control environmental pollution and improve resource allocation efficiency can be regarded as environmental protection inputs (Shen et al., 2021).

Corporate environmental investment is closely related to resource allocation, while innovation as a complex task with huge economic and social benefits requires a large amount of resource investment (Jia et al., 2019). In this context, the relationship between corporate environmental investment and innovation performance is inconclusive. On the one hand, increasing environmental investment is an important source of institutional legitimacy for firms (Li et al., 2018). On the other hand, excessive investment in environmental protection has taken up a lot of resources (Eyraud et al., 2013), thus limiting the development of innovation activities. These ambiguous and paradoxical findings also drive us to investigate how environmental investment affects corporate innovation, which is the main research question of this study.

We argue that increasing investment in environmental protection can bring resource advantages, specifically from the government, thus providing financial support for corporate innovation activities. In China, the government holds key business resources, and firms need to implement active environmental strategies or political activities to obtain institutional legitimacy and external 
resources such as subsidies, tax incentives, etc. (Wang and Qian, 2011). Thus, one important purpose of corporate environmental investment is to secure more government resources to promote corporate innovation activities.

We use a sample of Chinese industrial firms from 1998 to 2008 to test our hypotheses, and the results well support our arguments. The main contribution of this study is that, in contrast to previous studies that emphasize the economic benefits of corporate environmental investment, this study focuses on its driving force on innovation, which contributes to understanding the role of firms in technological and social changes. Furthermore, we emphasize the mechanism of government resources, which enriches the knowledge of the literature in corporate environmental management and innovation.

\section{BACKGROUND AND DEVELOPMENT OF HYPOTHESES}

\subsection{Research Background}

Along with the rapid economic development, environmental pollution comes with it. Faced with serious environmental problems, the Chinese government has shown an unprecedented attention, specifically to the role of firms in pollution control. As reported in the 14th Five-Year Plan, the government should strengthen the establishment of corporate environmental governance responsibility systems, and guide social organizations and the public to participate in environmental governance. In addition, the government also promotes firms to implement environmental protection activities through a variety of channels, including adopting compulsory environmental regulations (Delmas and MontesSancho, 2011) and sending legitimacy signal to guide firms to implement active environmental strategies (Marquis and Qian, 2014). Faced with environmental regulatory pressure and legitimacy requirements, most firms will increase environmental protection investment or participate in environmental innovation activities (Berrone et al., 2013).

On the other hand, after the reform and opening up, China's total economic volume has risen rapidly, but the quality of economic and social development is still lacking due to the lack of overall independent innovation capabilities. Under the new situation that China's economy is shifting from high-speed growth to high-quality growth, the Chinese government has placed innovation at the center of the national development and actively guided firms to participate in innovation activities. Innovation is not only an important driving force for the development of social productivity, but also an important force for the transformation of social production relations and the development of human culture, and hence has important social benefits. However, innovation is fraught with uncertainty and has a high risk of failure (Holmstrom, 1989), and is influenced by many factors, such as corporate and public governance (Jia et al., 2019), the nature of ownership (Choi et al., 2011), government support (Ji and Miao, 2020) and political connections (Hou et al., 2017). The government provides policy guidance for corporate innovation, and the resources it has are also an important factor in supporting corporate innovation activities, such as special government subsidies for firms to promote technological innovations in specific governmentencouraged areas.

\subsection{Corporate Environmental Investment and Innovation}

Existing research shows that the survival and development of organizations need resources. However, the organization does not usually produce such resources, and its performance depends on its ability to interact with the environment to obtain key resources (Hillman et al., 2009). The same is true for corporate innovation. When a firm lacks sufficient resources to maintain innovation activities, its innovation performance will suffer huge losses. In China, most of these resources are controlled by the government (Li et al., 2008), and the allocation of resources is inefficient, so that firms with better institutional legitimacy may receive more resources, such as government subsidies (Lin et al., 2015). Therefore, proper interaction with the government is one of the important means of obtaining resources.

We have mentioned that environmental pollution has attracted important attention from the Chinese government. Facing the government's environmental protection appeal, appropriate feedback on government behavior is one of the important channels for firms to obtain the institution legitimacy (Marquis et al., 2011). In China, the lack of a sound legal governance system makes the government's decision-making process less transparent and inefficient in the allocation of some resources (He and Tian, 2008). In order to obtain resources and reduce the uncertainty in the business process, firms may choose to actively respond to the government's call to obtain legitimacy and important commercial resources (Marquis and Qian, 2014). Therefore, we argue that firms that choose to increase environmental investment are more likely to obtain institutional legitimacy and government subsidies. As a key political resource, government subsidies can provide sufficient financial support for the innovation activities and help firms reduce the costs and risks during the innovation process (Wang et al., 2017). We propose:

Hypothesis 1. Increasing investment in environmental protection can help firms obtain more government subsidies, thereby improving corporate innovation.

\section{METHODOLOGY}

\subsection{Sample and Data Collection}

In order to investigate the impact of environmental investment on corporate innovation, A total of 31,024 Chinese industrial firms from 1998 to 2008 were used as the research sample. During the 10 years from 1998 to 2008, the Chinese government issued the Ninth and Tenth Five-Year Plans, which have been mentioned many times to increase environmental governance 
and guide firms to control environmental pollution, providing us an ideal context to test our hypotheses. The industrial firm data was collected from the Annual Census of Industrial Enterprises (ACIE), which includes all industrial firms above designated size in China. Corporate environmental data came from the Environmental Survey and Reporting (ESR) database compiled by the Ministry of Ecology and Environment of China. Corporate patent data was sourced from the Chinese Patent database. Regional characteristic data were obtained from the "China Statistical Yearbook" and the "China City Statistical Yearbook."

\subsection{Measures}

\subsubsection{Corporate Innovation}

We used the total number of patent applications of a firm in a given year to measure Corporate innovation (Jia et al., 2019). In addition, we also used the sales revenue of new products as an alternative measure for corporate innovation.

\subsubsection{Environmental Investment}

We used the natural logarithm of the number of wastewater treatment facilities to measure the level of corporate Environmental investment. Wastewater treatment is one of the important contents of the Chinese government's environmental pollution governance, and the quality of the water environment is also listed as one of the main indicators of ecological environmental protection in the 13th Five-Year Plan.

\subsubsection{Other Variables}

Government subsidies was measured by the natural logarithm of corporate subsidy incomes from the government. Firm size was measured by the natural logarithm of firm total assets. Firm age was measured by the years of a firm's establishment. Debt ratio was measured as a firm's debt-to-asset ratio. Financial performance was measured as the return on assets. Government jurisdiction captures the level of government to which a firm is affiliated, and was measured as an ordered variable, coded as 1 for town-level government and below, 2 for county-level government, 3 for prefecture-level government, 4 for provincial government, and 5 for central government. Regional marketization was expressed by the marketization index. Regional corruption was calculated by the number of cases of corruption per 10,000 civil servants at the provincial level. Regional economic development was measured as the natural logarithm of the municipal gross domestic product (GDP).

\subsection{Estimation Method}

In order to test the role of environmental protection investment and government subsidies on corporate innovation, this study used a stepwise test coefficient method to test the mediating role of government subsidies between environmental investment and corporate innovation performance with a bootstrap model to perform 500 cycles of calculation (Baron and Kenny, 1986). We conducted an ordinary least-squares (OLS) regression absorbing year-level and industry-level fixed effect with a robust variance covariance estimator. The model was set as follows:

$$
\begin{aligned}
& \text { Corporate innovation }=\beta_{0}+\beta_{1} \text { Environmental investment } \\
& +\beta_{2} \text { Controls }+\varepsilon \\
& +\beta_{5} \text { Controls }+\varepsilon
\end{aligned}
$$

where $\beta_{1}, \beta_{4}, \beta_{7}$ and $\beta_{8}$ are used to test Hypothesis 1; "Controls" is the set of control variables; $\varepsilon$ represents the random error term.

\section{RESULTS}

\subsection{Descriptive Statistics and Correlation}

Table 1 reports the results of descriptive statistics and correlations of all variables. It can be seen that environmental investment and corporate innovation are positively correlated $(p<0.05)$, and the correlation coefficient between the independent variable and any other variables is less than 0.5 . In addition, the average value of the variance inflation factor (VIF) is 1.28 , which is significantly less than 10. Therefore, the risk of multicollinearity in this study is excluded.

\subsection{Hypotheses Testing}

Table 2 reports the regression results estimated by government subsidies and corporate innovation. Hypothesis 1 states that environmental investment can improve corporate innovation performance through obtaining government subsidies. As shown in Model 2, the coefficient on environmental investment is positive and significant at the $0.1 \%$ level $(\beta=0.166, p<0.001)$, suggesting that firms investing more in environmental protection can receive more government subsidies. In Model 3, the coefficient on government subsidies is positive and significant at the $0.1 \%$ level $(\beta=0.008, p<0.001)$, suggesting that firms that received more government subsidies can have better innovation performance, thus supporting for Hypothesis 1.

We also conducted several analyses to test the robustness. An alternative measure of the dependent variable to check the significance was used in the regression (Yao et al., 2021). In Models 4-6 of Table 2, we used the natural logarithm value of new product sales revenue to measure corporate innovation and found that the results remained similar. Furthermore, government subsidies and patents may have many zero values. To fill this gap, we used a Tobit regression for robustness check. As show in Model 7-9 of Table 2, the regression results still support for Hypothesis 1.

\section{DISCUSSION AND CONCLUSION}

Innovation is an important source for firms to maintain vitality and improve competitiveness. In the context of increasingly stringent environmental supervision, how to balance the development of environmental governance and innovation activities has become an important issue that firms need to solve in the future. We used an empirical analysis to investigate how environmental investment affects corporate innovation. We found that increasing investment in 
TABLE 1 | Descriptive statistics and correlation matrix.

\begin{tabular}{|c|c|c|c|c|c|c|c|c|c|c|c|c|}
\hline Variables & Mean & SD & (1) & (2) & (3) & (4) & (5) & (6) & (7) & (8) & (9) & (10) \\
\hline (1) Corporate innovation (patent) & 0.101 & 0.436 & & & & & & & & & & \\
\hline (2) Firm size & 10.951 & 1.552 & 0.290 & & & & & & & & & \\
\hline (3) Firm age & 15.959 & 16.829 & 0.105 & 0.220 & & & & & & & & \\
\hline (4) Debt ratio & 0.584 & 0.231 & -0.018 & 0.014 & 0.093 & & & & & & & \\
\hline (5) Financial performance & 0.056 & 0.259 & 0.004 & -0.046 & -0.064 & -0.129 & & & & & & \\
\hline (6) Government jurisdiction & 1.812 & 1.167 & 0.139 & 0.377 & 0.471 & 0.031 & -0.083 & & & & & \\
\hline (7) Regional marketization & 7.323 & 1.959 & 0.051 & -0.011 & -0.164 & -0.033 & 0.047 & -0.313 & & & & \\
\hline (8) Regional corruption & 33.357 & 10.008 & -0.035 & -0.053 & 0.094 & 0.062 & -0.034 & 0.099 & -0.355 & & & \\
\hline (9) Regional economic development & 16.161 & 1.036 & 0.100 & 0.130 & 0.064 & -0.021 & 0.018 & 0.014 & 0.497 & -0.180 & & \\
\hline (10) Subsidy income & 1.377 & 2.749 & 0.125 & 0.268 & 0.094 & 0.018 & -0.016 & 0.113 & 0.061 & -0.003 & 0.037 & \\
\hline (11) Environmental investment & 0.592 & 0.493 & 0.124 & 0.304 & 0.012 & -0.018 & 0.024 & 0.075 & 0.072 & -0.116 & 0.032 & 0.106 \\
\hline
\end{tabular}

Note: $\mathrm{N}=85,279$; correlation greater than $|0.02|$ are significant at the 0.05 level.

TABLE 2 | Estimates for corporate innovation performance.

\begin{tabular}{|c|c|c|c|c|c|c|c|c|c|}
\hline \multirow[t]{2}{*}{ Variables } & $\begin{array}{c}\text { DV: } \\
\text { Patent }\end{array}$ & $\begin{array}{c}\text { DV: } \\
\text { Subsidy }\end{array}$ & $\begin{array}{c}\text { DV: } \\
\text { Patent }\end{array}$ & $\begin{array}{c}\text { DV: } \\
\text { Sales }\end{array}$ & $\begin{array}{c}\text { DV: } \\
\text { Subsidy }\end{array}$ & $\begin{array}{c}\text { DV: } \\
\text { Sales }\end{array}$ & $\begin{array}{c}\text { DV: } \\
\text { Patent }\end{array}$ & $\begin{array}{c}\text { DV: } \\
\text { Subsidy }\end{array}$ & $\begin{array}{c}\text { DV: } \\
\text { Patent }\end{array}$ \\
\hline & $\begin{array}{c}\text { Model } \\
1\end{array}$ & $\begin{array}{c}\text { Model } \\
2\end{array}$ & $\begin{array}{c}\text { Model } \\
3\end{array}$ & $\begin{array}{c}\text { Model } \\
4\end{array}$ & $\begin{array}{c}\text { Model } \\
5\end{array}$ & $\begin{array}{c}\text { Model } \\
6\end{array}$ & $\begin{array}{c}\text { Model } \\
7\end{array}$ & $\begin{array}{c}\text { Model } \\
8\end{array}$ & $\begin{array}{c}\text { Model } \\
9\end{array}$ \\
\hline Firm size & $\begin{array}{c}0.078^{\star \star \star} \\
(0.002)\end{array}$ & $\begin{array}{c}0.454^{\star \star \star} \\
(0.008)\end{array}$ & $\begin{array}{c}0.065^{\star \star \star} \\
(0.002)\end{array}$ & $\begin{array}{c}0.659^{\star \star \star} \\
(0.011)\end{array}$ & $\begin{array}{c}0.454^{\star \star \star} \\
(0.008)\end{array}$ & $\begin{array}{c}0.643^{\star \star \star} \\
(0.011)\end{array}$ & $\begin{array}{c}0.776^{\star \star \star} \\
(0.013)\end{array}$ & $\begin{array}{c}1.693^{* * *} \\
(0.030)\end{array}$ & $\begin{array}{c}0.743^{\star \star \star} \\
(0.015)\end{array}$ \\
\hline Firm age & $\begin{array}{l}0.001^{\star \star \star} \\
(0.000)\end{array}$ & $\begin{array}{c}0.008^{\star \star \star} \\
(0.001)\end{array}$ & $\begin{array}{l}0.001^{\star \star \star} \\
(0.000)\end{array}$ & $\begin{array}{c}0.023^{\star \star \star} \\
(0.001)\end{array}$ & $\begin{array}{c}0.008^{\star \star \star} \\
(0.001)\end{array}$ & $\begin{array}{c}0.023^{\star \star \star} \\
(0.001)\end{array}$ & $\begin{array}{c}0.006^{\star \star \star} \\
(0.001)\end{array}$ & $\begin{array}{c}0.026^{\star \star \star} \\
(0.003)\end{array}$ & $\begin{array}{c}0.006^{\star \star \star} \\
(0.001)\end{array}$ \\
\hline Debt ratio & $\begin{array}{c}0.008^{\star \star \star} \\
(0.002)\end{array}$ & $\begin{array}{c}0.143^{\star \star \star} \\
(0.035)\end{array}$ & $\begin{array}{c}-0.037^{\star \star \star} \\
(0.006)\end{array}$ & $\begin{array}{c}0.144^{\star \star \star} \\
(0.009)\end{array}$ & $\begin{array}{c}0.143^{\star \star \star} \\
(0.035)\end{array}$ & $\begin{array}{c}0.010 \\
(0.058)\end{array}$ & $\begin{array}{c}0.111^{\star \star \star} \\
(0.011)\end{array}$ & $\begin{array}{c}0.656^{\star \star *} \\
(0.178)\end{array}$ & $\begin{array}{c}-0.361^{\star \star \star} \\
(0.080)\end{array}$ \\
\hline Financial performance & $\begin{array}{l}0.010^{\star \star \star} \\
(0.002)\end{array}$ & $\begin{array}{l}-0.020 \\
(0.028)\end{array}$ & $\begin{array}{c}0.026 \\
(0.019)\end{array}$ & $\begin{array}{c}0.123^{\star \star \star} \\
(0.018)\end{array}$ & $\begin{array}{l}-0.020 \\
(0.028)\end{array}$ & $\begin{array}{c}0.287 \\
(0.237)\end{array}$ & $\begin{array}{c}0.100^{\star \star \star} \\
(0.019)\end{array}$ & $\begin{array}{c}-1.613^{\star \star \star} \\
(0.327)\end{array}$ & $\begin{array}{c}0.164^{\star \star \star} \\
(0.044)\end{array}$ \\
\hline Government jurisdiction & $\begin{array}{c}0.010^{\star \star *} \\
(0.002)\end{array}$ & $\begin{array}{c}0.093^{\star \star \star} \\
(0.012)\end{array}$ & $\begin{array}{c}0.008^{\star \star \star} \\
(0.002)\end{array}$ & $\begin{array}{c}0.349^{\star \star \star} \\
(0.016)\end{array}$ & $\begin{array}{c}0.093^{\star \star \star} \\
(0.012)\end{array}$ & $\begin{array}{c}0.322^{\star \star \star} \\
(0.018)\end{array}$ & $\begin{array}{c}0.109^{\star \star \star} \\
(0.015)\end{array}$ & $\begin{array}{c}0.338^{\star \star \star} \\
(0.041)\end{array}$ & $\begin{array}{c}0.097^{\star \star \star} \\
(0.016)\end{array}$ \\
\hline Regional marketization & $\begin{array}{c}0.008^{\star \star \star} \\
(0.001)\end{array}$ & $\begin{array}{c}0.147^{\star \star \star} \\
(0.007)\end{array}$ & $\begin{array}{c}0.008^{\star \star \star} \\
(0.001)\end{array}$ & $\begin{array}{c}0.132^{\star \star \star} \\
(0.009)\end{array}$ & $\begin{array}{c}0.147^{\star \star \star} \\
(0.007)\end{array}$ & $\begin{array}{c}0.119^{\star \star \star} \\
(0.010)\end{array}$ & $\begin{array}{c}0.116^{\star \star \star} \\
(0.012)\end{array}$ & $\begin{array}{c}0.729^{\star \star \star} \\
(0.03)\end{array}$ & $\begin{array}{c}0.125^{\star \star \star} \\
(0.013)\end{array}$ \\
\hline Regional corruption & $\begin{array}{c}0.000 \\
(0.000)\end{array}$ & $\begin{array}{c}0.016^{\star \star \star} \\
(0.001)\end{array}$ & $\begin{array}{c}0.000 \\
(0.000)\end{array}$ & $\begin{array}{c}0.026^{\star \star \star} \\
(0.001)\end{array}$ & $\begin{array}{c}0.016^{\star \star \star} \\
(0.001)\end{array}$ & $\begin{array}{c}0.026^{\star \star \star} \\
(0.002)\end{array}$ & $\begin{array}{c}0.003 \\
(0.002)\end{array}$ & $\begin{array}{c}0.076^{\star \star \star} \\
(0.005)\end{array}$ & $\begin{array}{c}0.002 \\
(0.002)\end{array}$ \\
\hline Regional economic development & $\begin{array}{l}0.011^{\star \star \star} \\
(0.002)\end{array}$ & $\begin{array}{c}-0.102^{\star \star \star} \\
(0.011)\end{array}$ & $\begin{array}{c}0.010^{\star \star \star} \\
(0.002)\end{array}$ & $\begin{array}{c}-0.139^{\star \star \star} \\
(0.014)\end{array}$ & $\begin{array}{c}-0.102^{\star \star \star} \\
(0.011)\end{array}$ & $\begin{array}{c}-0.121^{\star \star \star} \\
(0.014)\end{array}$ & $\begin{array}{l}0.101^{\star \star \star} \\
(0.018)\end{array}$ & $\begin{array}{c}-0.370^{\star \star \star} \\
(0.045)\end{array}$ & $\begin{array}{c}0.097^{\star \star \star} \\
(0.020)\end{array}$ \\
\hline Environmental investment & $\begin{array}{c}0.052^{\star \star \star} \\
(0.005)\end{array}$ & $\begin{array}{c}0.166^{\star \star \star} \\
(0.022)\end{array}$ & $\begin{array}{c}0.048^{\star \star \star} \\
(0.005)\end{array}$ & $\begin{array}{l}0.224^{\star \star \star} \\
(0.031)\end{array}$ & $\begin{array}{c}0.166^{\star \star \star} \\
(0.022)\end{array}$ & $\begin{array}{c}0.182^{\star \star \star} \\
(0.033)\end{array}$ & $\begin{array}{l}0.172^{\star \star \star} \\
(0.034)\end{array}$ & $\begin{array}{l}0.362^{\star \star \star} \\
(0.084)\end{array}$ & $\begin{array}{c}0.130^{\star \star \star} \\
(0.035)\end{array}$ \\
\hline Government subsidies & & & $\begin{array}{l}0.008^{\star \star \star} \\
(0.001)\end{array}$ & & & $\begin{array}{l}0.080^{\star \star \star} \\
(0.006)\end{array}$ & & & $\begin{array}{l}0.049^{\star \star \star} \\
(0.006)\end{array}$ \\
\hline Constant & $\begin{array}{c}-1.041^{\star \star \star} \\
(0.032)\end{array}$ & $\begin{array}{c}-4.030^{\star \star \star} \\
(0.169)\end{array}$ & $\begin{array}{c}-0.876^{\star \star \star} \\
(0.031)\end{array}$ & $\begin{array}{c}-6.317^{\star \star \star} \\
(0.227)\end{array}$ & $\begin{array}{c}-4.030^{\star \star \star} \\
(0.169)\end{array}$ & $\begin{array}{c}-6.327^{\star \star \star} \\
(0.239)\end{array}$ & $\begin{array}{c}-16.604^{\star \star \star} \\
(0.422)\end{array}$ & $\begin{array}{c}-29.311^{\star \star \star} \\
(0.908)\end{array}$ & $\begin{array}{c}-15.949^{\star \star \star} \\
(0.463)\end{array}$ \\
\hline Industry dummies & Included & Included & Included & Included & Included & Included & Included & Included & Included \\
\hline Year dummies & Included & Included & Included & Included & Included & Included & Included & Included & Included \\
\hline Adj R-squared & 0.105 & 0.120 & 0.233 & 0.224 & 0.105 & 0.233 & 0.176 & 0.040 & 0.176 \\
\hline Wald/LR chi2 & $2,927.21^{\star \star \star}$ & $5,713.72^{\star \star \star}$ & $2,376 \cdot 34^{\star \star \star}$ & $7,728.73^{\star \star \star}$ & $5,713.72^{\star \star \star}$ & $8,278.8^{\star \star \star}$ & $13,057.78^{\star \star \star}$ & $7,756.80^{\star \star \star}$ & $10,401 \cdot 73^{\star \star \star}$ \\
\hline Observations & 96,906 & 85,849 & 85,279 & 84,034 & 85,849 & 70,481 & 96,908 & 85,852 & 85,282 \\
\hline
\end{tabular}

Note: ${ }^{* *} \mathrm{p}<0.001,{ }^{* *} \mathrm{p}<0.01,{ }^{*} \mathrm{p}<0.05$; standard errors are in parentheses.

environmental protection can significantly promote corporate innovation. As investment in environmental protection is an important mean to secure institutional legitimacy, firms can obtain resources controlled by the government by implementing active environmental strategies, thereby helping firms with more resources to invest in innovation activities.

\subsection{Contribution}

The main contribution of this study is that we emphasize the mechanism for firms to obtain effective resources to promote innovation through environmental investment, which enriches the knowledge in the literature of both corporate environmental management and innovation (Staub et al., 2016; Boone et al., 2019). Furthermore, compared with the previous literature focusing on the economic benefits of environmental, social and governance (ESG) investment (Baron and Kenny, 1986), we pay more attention to its social impact.

More practically, this study responds to the call for environment protection, and provides new insights for policy makers to better manage corporate environmental action. For firms, this study provides empirical evidence for how firms can 
interact with government effectively to obtain external resources and improve corporate innovation.

\subsection{Limitation and Future Research}

Our study has some limitations. First, our sample only includes the industrial firms above designated size and lacks the consideration for some small and medium-sized firms, which should be considered for future research. Second, considering the diversity of pollutant emissions, we have limitations in capturing corporate wastewater treatment facilities to measure environmental investment. Future research may consider more effective indicators to measure corporate environmental investment.

\section{REFERENCES}

Baron, R. M., and Kenny, D. A. (1986). The Moderator-Mediator Variable Distinction in Social Psychological Research: Conceptual, Strategic, and Statistical Considerations. J. Personal. Soc. Psychol. 51, 1173-1182. doi:10.1037/0022-3514.51.6.1173

Berrone, P., Fosfuri, A., Gelabert, L., and Gomez-Mejia, L. R. (2013). Necessity as the Mother of 'green' Inventions: Institutional Pressures and Environmental Innovations. Strat. Mgmt. J. 34, 891-909. doi:10.1002/smj.2041

Boone, C., Lokshin, B., Guenter, H., and Belderbos, R. (2019). Top Management Team Nationality Diversity, Corporate Entrepreneurship, and Innovation in Multinational Firms. Strat Mgmt J. 40, 277-302. doi:10.1002/smj.2976

Choi, S. B., Lee, S. H., and Williams, C. (2011). Ownership and Firm Innovation in a Transition Economy: Evidence from China. Res. Pol. 40, 441-452. doi:10.1016/j.respol.2011.01.004

Delmas, M. A., and Montes-Sancho, M. J. (2011). U.S. State Policies for Renewable Energy: Context and Effectiveness. Energy Policy 39 (5), 2273-2288. doi:10.1016/j.enpol.2011.01.034

Eyraud, L., Clements, B., and Wane, A. (2013). Green Investment: Trends and Determinants. Energy Policy 60, 852-865. doi:10.1016/j.enpol.2013.04.039

Hao, Y., Peng, H., Temulun, T., Liu, L.-Q., Mao, J., Lu, Z.-N., et al. (2018). How Harmful Is Air Pollution to Economic Development? New Evidence from PM2.5 Concentrations of Chinese Cities. J. Clean. Prod. 172, 743-757. doi:10.1016/j.jclepro.2017.10.195

He, Y., and Tian, Z. (2008). Government-oriented Corporate Public Relation Strategies in Transitional China. Manag. Organ. Rev. 4, 367-391. doi:10.1111/ j.1740-8784.2008.00119.x

Hillman, A. J., Withers, M. C., and Collins, B. J. (2009). Resource Dependence Theory: A Review. J. Manage. 35, 1404-1427. doi:10.1177/0149206309343469

Holmstrom, B. (1989). Agency Costs and Innovation. J. Econ. Behav. Organ. 12, 305-327. doi:10.1016/0167-2681(89)90025-5

Hou, Q., Hu, M., and Yuan, Y. (2017). Corporate Innovation and Political Connections in Chinese Listed Firms. Pacific-Basin Finance J. 46, 158-176. doi:10.1016/j.pacfin.2017.09.004

Ji, H., and Miao, Z. (2020). Corporate Social Responsibility and Collaborative Innovation: The Role of Government Support. J. Clean. Prod. 260, 121028. doi:10.1016/j.jclepro.2020.121028

Jia, N., Huang, K. G., and Man Zhang, C. (2019). Public Governance, Corporate Governance, and Firm Innovation: An Examination of State-Owned Enterprises. Amj 62, 220-247. doi:10.5465/amj.2016.0543

Klettner, A., Clarke, T., and Boersma, M. (2014). The Governance of Corporate Sustainability: Empirical Insights into the Development, Leadership and Implementation of Responsible Business Strategy. J. Bus. Ethics 122, 145-165. doi:10.1007/s10551-013-1750-y

Li, D., Huang, M., Ren, S., Chen, X., and Ning, L. (2018). Environmental Legitimacy, Green Innovation, and Corporate Carbon Disclosure: Evidence from CDP China 100. J. Bus. Ethics 150, 1089-1104. doi:10.1007/s10551-016-3187-6

Li, H., Meng, L., Wang, Q., and Zhou, L.-A. (2008). Political Connections, Financing and Firm Performance: Evidence from Chinese Private Firms. J. Develop. Econ. 87, 283-299. doi:10.1016/j.jdeveco.2007.03.001

\section{DATA AVAILABILITY STATEMENT}

The original contributions presented in the study are included in the article/supplementary material, further inquiries can be directed to the corresponding author.

\section{AUTHOR CONTRIBUTIONS}

WL and RP led the conceptual design of the manuscript, YBX wrote the initial drafts, RP advised the formal analysis and all authors reviewed the manuscript and provided comments and feedback.

Lin, H., Zeng, S. X., Ma, H. Y., and Chen, H. Q. (2015). How Political Connections Affect Corporate Environmental Performance: The Mediating Role of green Subsidies. Hum. Ecol. Risk Assess. Int. J. 21, 2192-2212. doi:10.1080/10807039.2015.1044937

Liu, W., Xu, Y., Fan, D., Li, Y., Shao, X.-F., and Zheng, J. (2021). Alleviating Corporate Environmental Pollution Threats toward Public Health and Safety: The Role of Smart City and Artificial Intelligence. Saf. Sci. 143, 105433. doi:10.1016/j.ssci.2021.105433

Marquis, C., and Qian, C. (2014). Corporate Social Responsibility Reporting in China: Symbol or Substance. Organ. Sci. 25, 127-148. doi:10.1287/orsc.2013.0837

Marquis, C., Zhang, J., and Zhou, Y. (2011). Regulatory Uncertainty and Corporate Responses to Environmental protection in China. Calif. Manage. Rev. 54, 39-63. doi:10.1525/cmr.2011.54.1.39

Porter, M. E., and Linde, C. v. d. (1995). Toward a New conception of the Environment-Competitiveness Relationship. J. Econ. Perspect. 9, 97-118. doi:10.1257/jep.9.4.97

Shen, Y., Su, Z.-W., Malik, M. Y., Umar, M., Khan, Z., and Khan, M. (2021). Does green Investment, Financial Development and Natural Resources Rent Limit Carbon Emissions? A Provincial Panel Analysis of China. Sci. Total Environ. 755, 142538. doi:10.1016/j.scitotenv.2020.142538

Staub, S., Kaynak, R., and Gok, T. (2016). What Affects Sustainability and Innovation - Hard or Soft Corporate Identity. Technol. Forecast. Soc. Change 102, 72-79. doi:10.1016/j.techfore.2015.06.033

Wang, C., Nie, P.-y., Peng, D.-h., and Li, Z.-h. (2017). Green Insurance Subsidy for Promoting Clean Production Innovation. J. Clean. Prod. 148, 111-117. doi:10.1016/j.jclepro.2017.01.145

Wang, H., and Qian, C. (2011). Corporate Philanthropy and Corporate Financial Performance: The Roles of Stakeholder Response and Political Access. Amj 54, 1159-1181. doi:10.5465/amj.2009.0548

Wang, R., Wijen, F., and Heugens, P. P. M. A. R. (2018). Government's green Grip: Multifaceted State Influence on Corporate Environmental Actions in China. Strat Mgmt J. 39, 403-428. doi:10.1002/smj.2714

Yao, H., Liu, W., Wu, C.-H., and Yuan, Y.-H. (2021). The Imprinting Effect of SARS Experience on the Fear of COVID-19: The Role of AI and Big Data. SocioEconomic Plann. Sci. 101086, 101086. doi:10.1016/j.seps.2021.101086

Conflict of Interest: The authors declare that the research was conducted in the absence of any commercial or financial relationships that could be construed as a potential conflict of interest.

Publisher's Note: All claims expressed in this article are solely those of the authors and do not necessarily represent those of their affiliated organizations, or those of the publisher, the editors and the reviewers. Any product that may be evaluated in this article, or claim that may be made by its manufacturer, is not guaranteed or endorsed by the publisher.

Copyright $\odot 2021 \mathrm{Xu}, \mathrm{Liu}, \mathrm{Pu}$ and $\mathrm{Xu}$. This is an open-access article distributed under the terms of the Creative Commons Attribution License (CC BY). The use, distribution or reproduction in other forums is permitted, provided the original author(s) and the copyright owner(s) are credited and that the original publication in this journal is cited, in accordance with accepted academic practice. No use, distribution or reproduction is permitted which does not comply with these terms. 